\title{
Motor Neuron
}

National Cancer Institute

\section{Source}

National Cancer Institute. Motor Neuron. NCI Thesaurus. Code C12644.

An efferent neuron that sends impulses from the central nervous system to skeletal muscles. 